\title{
An Ethical Literary Analysis of The Girlhood of Shakespeare's Heroines ${ }^{1}$
}

\author{
JI RANGPING
}

\begin{abstract}
The Girlhood of Shakespeare's Heroines, a classic Shakespeare drama adaptation by Mary Cowden Clarke, tells the girlhood stories of Shakespeare's heroines in a series of fifteen tales. Analysing the tales from the perspective of ethical literary criticism and the theory of the Sphinx factor (an original critical theory formulated by the Chinese scholar Nie Zhenzhao), this paper explores such ethical and social problems as the double standards of sex ethics and the inequalities between man and woman by means of the Animal factor analysis and argues that by disclosing these problems in a deliberately abhorrent way, the tales fulfil the task of ethically educating Victorian readers, and female readers in particular, in an enlightening and entertaining way while leading Victorian women to the appreciation of Shakespeare's plays.
\end{abstract}

Keywords: Ethical Literary Criticism; The Girlhood of Shakespeare's Heroines; Mary Cowden Clarke; animal factor; sex ethics; double standards

\section{Introduction}

As the author of The First Complete Concordance to Shakespeare (1854), Mary Cowden Clarke (1809-1898) is best known as "a popular writer, a Shakespearean scholar and critic for the masses, and... a teacher of her vast audience on the subject of Victorian womanhood" (Gross 1972: 38), who attempted to guide Victorian female readers toward an appreciation of Shakespeare's works, and more importantly an ethical education through her writings such as The Girlhood of Shakespeare's Heroines (1850-1852), a series of prequels to Shakespeare's plays

1 This article is funded by “The Study of Shakespeare's Plays Adapted in British Children's Literature (1807-1901)", a project of Humanities and Social Science Research (Youth Funds) of Education Ministry of China (Serial No.1702120, Grant No.17YJC752010, 2017); funded by "An Ethical Literary Criticism Interpretation of Shakespeare's Plays Adapted for Children's Literature in Victorian UK", a project of Education Department of Jilin Province (Serial No.1705220, Grant No.JJKH20170948SK, 2017); and also funded by "The Research of American Young Adult History Novels from the Perspective of Ethical Literary Criticism”, a project of Education Department of Jilin Province (Serial No. 1505217, 2015).

DOI: https://doi.org/10.12697/IL.2018.23.1.7 
JI

that enjoyed great popularity and high acclaim among women readers upon its publication and had a revival in recent years after a period of oblivion.

Clarke entered the almost-exclusively masculine world of Shakespearean studies in mid-nineteenth century, a period that is noted for its high and strict ethical standards and a set of ethical values that highlight sexual repression, low tolerance of crime, and a strong social ethics. Like many Victorian female writers who were educated and thus able to express their opinions about social issues they were concerned about, she also contemplated such problems as poverty, child labour, and prostitution. While incorporating these problems into her fifteen tales as "possible circumstances and influences of scene, event, and associate, surrounding the infant life of his heroines, which might have conduced to originate and foster those germs of character recognized in their maturity, as by him developed" (Clarke 2009: preface iii), she presents in a straightforward manner the relationship between men and women, and that of family members, and enlightens her readers of both genders about the very existence of various ethical problems related to sex and social inequality.

Victorian sex ethics is closely related to Victorian "imperial prudery" (Foucault 1978: 3), which is characterized by "restrained, mute, and hypocritical sexuality" (Foucault 1978: 3). The rising Victorian bourgeoisie carefully confined sexuality to the home as a utilitarian and fertile locus and made silence the rule on the subject of sex for other family members (Foucault 1978: 3). On the other hand, however, as an emergent social and political force, they "chose sexuality as the basis for delineating their identity from the aristocracy, peasants and emergent working classes. ...The polarization of public and private spheres becomes the foundation upon which the ascendant bourgeoisie constructed the family and its sexuality. The passionless reproductive wife confined to private domesticity, along with her publicly and competitively orientated husband becomes the central reference point for discussions concerning sexuality (Victorian Sexuality 2016). In other words, double standards for men and women are one of the most dominant features of Victorian sex ethics. Living in an era full of clashing contradictions such as prosperity and poverty, repression and prudery, high cultural morals and low vulgarity, strict moral codes and debauchery, angels at home and prostitutes, etc., Victorians are supposed to have followed the double standards of sex ethics, under which men are the dominant rule-makers and vested interest group who are entitled to not only loose ethical requirements for themselves but also the qualification to define the relationship between power and sex in terms of repression against women, while women are required to obey strict and rigid codes of sex ethics, being deprived of access to necessary sex education and repressed not to have any sexual desire. In the 1800 s, the strict beliefs of procreation only and gender roles returned. Women 
An Ethical Literary Analysis of The Girlhood of Shakespeare's Heroines

were seen as having no sexuality and their role was to service their husbands. Having sexual desire was thought to be the sole prerogative of men and women of the lower classes. When a woman did express sexual desire, it was seen as a disease that needed to be taken care of immediately and with drastic measures like removing the sex organs. Sexual desire was thought to be a quality that only men should have in this time period. (Pastor et al. 2016)

It is under such circumstances that Clarke adapted Shakespeare's plays and wrote the girlhood tales of his heroines, with a conscious didactic intent to foster in the tales the sex ethics and other important moral values of her own day and class, and "the values that inform the 'tales' authorized by the name of Shakespeare have been credited with being timeless and 'universal."' (Bottoms 2004: 2) As an artistic reflection of the Victorian society and its sex ethics, The Girlhood Tales of Shakespeare's Heroines "may have offered Victorian girls a cautionary education about masculine sexual predation, as George Gross suggests, or even enacted the subversive, pre-feminist exploration of female autonomy that Sara Annes Brown praises (Gross 1972; Brown 2005)” (Quoted in Osborne 2015: 1). By truthfully uncovering the double standards of Victorian sex ethics, "these 'prequels' offer a backstory which is surprising in its subversive interpretation of the plays and especially of the role of the 'hero"' (Clarke 2009: preface) and an ideal of womanliness with such qualities of a "Shakespeare woman" as devotion, patience, generosity, and gentleness (Bottoms 2004: 8).

By means of ethical literary criticism and the theory of the Sphinx factor, this paper will explore in these tales Victorian ethics and sex ethics in particular, as well as the inequalities between male and female characters. Also, the didactic function of Shakespeare's drama adaptations in children's literature, embodied by Clarke's tales, and her significant efforts in the education of sex (ethics) and the promotion of Shakespeare and his works will be dealt with.

\section{The Animal Factor and Ethical Double Standards}

Guided by Victorian sex ethics, Clarke tells the girlhood tales of Shakespeare's heroines who live in a world "where men behave badly in mysteriously or alarmingly undermotivated ways" (Bottoms 2004: 7). In such a world as The Girlhood of Shakespeare's Heroines depict the unworldly, ignorant, and credulous female characters who are still in "their 'sallet days,' when they are 'green in judgment,'- immature, - but the opening buds of the future 'bright consummate flowers'” (Clarke 2009: prelude iv) are vulnerable to the lurking male predators and are likely to commit strings of costly missteps. Due to the lack of sex education, the unawareness of self-protection, the absence of life guides and 
JI

the imposition of rigid sex ethics, they tend to be captivated and trapped by the libertines, and thus have to be confronted with "disgrace, pollution, wreck of fair honour, peril of body and soul” (Clarke 2009: Tale VIII, P246), paying dearly for the irredeemable mistakes they unconsciously or involuntarily made. Horrifyingly bitter and painful lessons of girls cheated and bereft of virginity abound in the tales: Anna Nannie was coerced to be a woman of pleasure to make a living, Jutha died of giving birth to a dead infant, Thyra hanged herself in regret, Petronilla lived in poverty as a fugitive, and Juliet had to wait indefinitely to be Claudio's bride. That is to say, once straying from the ethical expectations of sex or violating relevant taboos, such as losing virginity before marriage or having extramarital affairs, they will be regarded as unchaste, fallen or ruined and have to pay dearly for the misdemeanours, either becoming prostitutes, being deserted, committing suicide or dying in childbirth. The tragic and pathetic fates of these victims alert female readers to be fully aware of the catastrophic and unamendable consequences of any transgression related to sex ethics, the importance of being self-disciplined, keeping chaste under any circumstances as well as abiding by all sex ethical codes specifically set for them, and most important of all, the recognition and acceptance of where they are in the double standard of sex ethics.

While the female characters are expected to adhere strictly to the ethical rules elaborately and specifically designed for them, the male predators who deem "the utilization of women as mere sexual tools to men's insatiable, animalistic, and, at times, predatory sexual ends" (Philaretou 2008: 86-87) meet much looser requirements about sexuality, and they are spoiled to such a degree that it is "charitable in the allowances it makes for the worker of all this evil, though severely tyrannous to the injured party." (Clarke 2009: Tale VIII, 246) Unethical, cruel and fatal as such deeds are, they are understated as "fashionable follies, and pardonable errors of youth" (Clarke 2009: Tale VIII, 246), and the male characters are basically immune to moral censorship, ethical criticism and any severe punishment for their evildoing, with the animal factor running free and wild in their veins.

The animal factor, as Nie Zhenzhao proposes in his "Ethical Literary Criticism: Ethical Choice and Sphinx Factor", is the animal instinct of man, and the lower-level and irrational half of the Sphinx factor, with the other half being the human factor. The human factor is the advanced part of the Sphinx factor, and it refers to the very factor that guarantees the coming into being of a real man who evolves from Savagery to Civilization. It is the very existence of the human factor that endows man with ethical consciousness and the ability to tell right from wrong and eventually converts one from animal to man. These two factors are in constant conflict and exert a great influence on man in his ethical 
choices. If the human factor holds the upper hand, man is rational, human, and ethically right; but if the animal factor, the remnant of the instinctive desire of the animal, takes over, then one is irrational and animal-like (Nie 2011: 1-13). The human factor and the animal factor are two co-existing, conflicting but interdependent factors in the Sphinx factor, with one being indispensable to the other just like the relationship between Yin and Yang, brightness and darkness, and they are one of many key terms in Nie's ethical literary criticism, "a critical theory that reads, analyzes and interprets literature from the perspective of ethics so as to identify its ethical nature and moral teaching function". (Nie 2014: 13)

In The Girlhood of Shakespeare's Heroines, the animal factor is highlighted and salient in the male predators and a few rebellious female characters, while the human factor falls into oblivion to a great extent. As far as the male characters are concerned, they are usually free to display their animal factor in various forms and can always easily get away with their unethical and even evil doings.

The most noticeable case of the animal factor in all the tales is represented in the "ugly odious" Ulf (Clarke 2009: Tale VIII, 197), the idiot son of Ophelia's nurse Botilda, in whom the human factor is completely overwhelmed by the animal factor, and he is depicted more like an animal or fiend-like creature than a man. The barbaric nature of Ulf is not only noticeable in his name that sounds like "wolf", and in his disgusting physical appearance with "cankered gums, and his yellow and black teeth, - some flat, like tombstones, - some long, narrow, and sharp, like the fangs of a dog" (Clarke 2009: Tale VIII, 215), but also illustrated more emphatically in his beastly acts of killing flies, eating singingbirds, stealing honey, tearing up a rose, and coveting the beauty of Ophelia by attempting to approach and even rape her by hiding himself under her bed at night. The scene in which the "cruel and malicious" (Clarke 2009: Tale VIII, 198) Ulf tears up a rose is the best example of the idiot-boy's acts resulting from the dominant animal factor in him - "it seemed a tyranny and a barbarity, as if inflicted on a sentient creature. Leaf after leaf fell, as if they were rent limbs. When he held up the bare stalk, the stripped calyx and yellow centre looked like a skeleton; and he twitched out the golden stamens, as though they were eyelashes, or teeth. He appeared to take a ferocious delight in ripping up and destroying flowers; and would pluck off the winged petals from sweet peas, as if he loved to deprive them of their seeming power of fairy flight. The vindictive satisfaction with which he exercised this power upon things of beauty and fragility, and the air of triumph with which he gloated over his work of ravage as he leered at her after each feat of the kind, made the little girl always feel somehow as if she were herself the bird, or the fly, or the rose, or whatsoever other object might chance to be the victim of Ulf's destructive propensity" 
JI

(Clarke 2009: Tale VIII, 198). This rose is a symbol of beautiful but fragile girls like Ophelia, and Ulf stands for the hideous and gluttonous male predators who have been totally taken up by the animal factor and are eager to satiate their sexual desires. The metaphor conveys the message that when fatalistically confronted with such a monster, the frail female characters are doomed to be devastated; for if not for pure luck, little Ophelia would have been ruined by the animal factor-stricken Ulf.

Similar to Ulf, male characters like Gabino and Marquis Fontana are also under the influence of the animal factor. They make no effort to hide their sexual desire; they resort to vulgar language or violence (rape) to fulfil their desire instead. In tale XIV, Gabino, the adopted son of Viola's great aunt Annuccia, was attracted by Viola's beauty and was spurred by his sexual desire to take full advantage of every occasion to get close to her and constantly harass her sexually. When this "odd beast" and "ill-bred animal" (Clarke 2009: Tale XIV, p365) usurped the belongings of Annuccia and became the master of the house, he threatened to kick Viola out of the house if she refused to become his mistress. If not for the lucky return of her father from overseas business, Viola would very likely have fallen prey to his naked lust. In the same tale, Marquis Fontana, who mistook Viola for a courtesan, was attracted by the beauty of Viola and was driven by his sexual desire to keep flirting her with words "proceeding from compliment into open flattery, and from flattery, into undisguised insult of admiration" (Clarke 2009: Tale XIV, 383) and some "still plainer and more offensive terms of adulation and proposal” (Clarke 2009: Tale XIV, 383).

In addition to the first form in which the animal factor subdues the human factor and the male characters plainly resort to vulgar language and violence to satisfy their instinctive animal desires, the second form looks relatively gentle but contains essentially more harmful and destructive power. It is easy for innocent girls to discern the apparently ill-intentioned male predators but equipped with little instruction and no education in sex, it is difficult and beyond their ability to tell a honey-lipped seduces from a truly worthy future partner, and many of them fall victim to those who hide their animal factor behind handsome appearance, good education, elegant etiquette, high social status, and/or great fortunes. Many examples can be found about these lecherous, scheming, callous and fraudulent male characters who are all driven by the animal factor to pursue the beauty, the wealth and/or the high social status of female characters by means of coaxing and cheating, among whom Lord Eric Kronstein, Chevalier Dorfaux, Marquis of Montferrat and the young duke of Milan are most typical.

Lord Eric of Kronstein was a practiced seducer and libertine, and he disguised his sexual desire for pretty girls and greed for wealth in such a good way that he 
succeeded in inducing both Jutha (a country lass and daughter of Ophelia's foster family) and Thyra (a graceful aristocratic lady and Ophelia's friend), and escaped with impunity, leaving Jutha a "white, still, rigid thing" (Clarke 2009: Tale VIII, 214) with "breathless, motionless lips and those eyelids, that looked fixed, rather than closed" (Clarke 2009: Tale VIII, 214) and Thyra "a mere heap of inanimate matter - an image, - a corse" (Clarke 2009: Tale VIII, 247) which was hanged among the curtains by "her own desperate hand" (Clarke 2009: Tale VIII, 247). Chevalier Dorfaux, a rogue who was as tricky as a fox, played the tricks of cheating no worse than Lord Eric. He enchanted "unpractised in the ways of the world, unsuspicious, unguarded" (Clarke 2009: Tale XII, 138) Astrella, the adopted sister of Olivia, with his "insinuating address, elegant person, and persevering court" (Clarke 2009: Tale XII, 138) and got the permission of her adoptive father to marry her. But after squandering away all their belongings, Dorfaux went away for merry-making, leaving pregnant Astrella and their daughter unattended. After the death of Astrella, he accidentally killed their daughter when taking revenge on her adoptive family, but he was not punished either. In another instance, the Marquis of Montferrat, who was later exposed as "a notorious and confirmed gambler, and an unscrupulous libertine" (Clarke 2009: Tale I, 68), concealed his infamy and coveted young Portia so well that if Portia's father Count Guido had not witnessed his seduction of and flirting with Nerissa, the waiting maid of Portia's, and had not been confirmed in his suspicions by a letter from his brother-in-law, he would have been deceived and married her daughter to this rogue. The young duke of Milan was a libertine of the same kind. While contriving to win the heart of Hero, he was attracted by Beatrice's wit and beauty, and decided to "amuse" himself with Beatrice, the “charming sparkler" (Clarke 2009: Tale XI, 80).

In other cases, the male predators are anonymous in the tales, which implies the pervasiveness of the lurking dangers around the innocent and naive girls. Anna Nanni, for example, was seduced by a man whose name readers cannot locate in the tale, and with her virginity being tricked out of her, she had no other option than to make a living as a woman of pleasure. As "a creature branded with sin, steeped in infamy" (Clarke 2009: Tale VI, 13) and "fallen among ruffian companions, insulted, outraged, spurned even by them", (Clarke 2009: Tale VI, 12) she had nothing in front of her but shame, torture and death.

And no matter how heinous the crimes the male predators committed, they could always get away with their unethical and evil doings - Lord Eric of Kronstein "under favour of darkness, embarked in a vessel bound for the Archipelago" (Clarke 2009: Tale VIII, 244), the Marquis of Mantferrat was just expelled from Portia's house and continued his deceiving elsewhere, the young duke of Milan turned to new targets when his scheme to pursue Hero and 
JI

Beatrice failed, and Chevalier Dorfaux was still at large after ruining Astrella and her adoptive family.

In contrast to the unruliness and prevalence of the animal factor in male predators, this factor is uncommon in female characters and if there is any trace of it, it is regarded as incompatible with the etiquette and ethical ideas of the Victorian society and therefore is to be ruthlessly get rid of. The morbid passion and love of Nina for Paola, Angelica's jealousy of her imaginary rivals in love, and the strong desire of Grouch for power are the most typical examples of the animal factor in female characters.

In Tale I, Nina was driven by "the constancy and fervour of her own passion" (Clarke 2009: Tale I, 319) for Paolo but, unfortunately, he was already deeply in love with Barbara. Obsessed by such negative feelings as disappointment, disillusionment, jealousy, fury, desperation and hatred, she "vowed to exchange her love for hate" (Clarke 2009: Tale I, 319). Then the destructive power of irrational love transformed her into a Medusa, and "with a look - one look such a look! - it turned him (Paola) to stone" (Clarke 2009: Tale I, 324). In the end, Paola went insane and died, Barbara died of grief and despair, and Nina disappeared for ever. The allusion to Medusa, a mortal gorgon who has the body of a woman, brazen claws for hands, and snakes for hair, reveals the conflict between the human factor and the animal factor in Nina. When the human factor is overwhelmed by the animal factor, the negative and destructive power destroys those involved in the affair.

Angelica, the wife of Lord Capulet and mother of Juliet, was beautiful and demure, but the sense of inferiority twisted her nature and she harboured her jealousy, wrath and hostility toward Giacinta and Leonilda deep down in her heart. Like Juno, the jealous and vindictive wife of Zeus, she was furious with these imaginary rivals and was obsessed with the desire to get rid of them: for the former, she painfully "contrived to stifle and shut up within herself the rage of jealousy that consumed her" (Clarke 2009: Tale X, 367); for the latter, she once came up with the idea of poisoning her and later subconsciously sponsored Onofrio to murder the lady. The natural deaths of the two saved her from the sense of guilt, but jealousy and sulking had tortured her for quite a long period.

Differently from Nina and Angelica who were driven by jealousy and wrath, Grouch (the young lady Macbeth) was characterized as an Amazon, the breastless woman warrior who was stereotyped as a violent, belligerent, aggressive and cold-blooded opponent and an obstacle to heroes' feats. Like an Amazon who would voluntarily cut off "the right breast to facilitate the use of a javelin” (Roman 2010: 56), Grouch grew out of feminine features and gradually acquired "a masculine spirit" (Clarke 2009: Tale II, 107) which was "resolute in achievement" (Clarke 2009: Tale II, 107) and "firm of purpose even unto death" 
An Ethical Literary Analysis of The Girlhood of Shakespeare's Heroines

(Clarke 2009: Tale II, 107). To attain her goals, she took little into consideration the ethical and social rules; for her, the end justified the means. To get the ball which accidentally fell on a branch, she cruelly overturned the nest with some baby birds in it and incited Culen to get the ball at the risk of his life; to prevent Macbeth from meeting Doada, she insistently sent Doada away to see her father in spite of the coming storm which finally took her life; to find out news about Macbeth, she sent Grym to the front despite the dangers on the way that led to Grym's being killed; to avoid any possible trouble, she lied to Macbeth about the true identity of Indulph who had just died for her.

However, whatever variations the animal factor in women characters may demonstrate, it is not consistent with the social ethics for women and therefore, it could only lead them to tragic fates: Medusa was killed by Perseus and Nina disappeared (being drowned or living in seclusion); Juno was obsessed with worries about her husband's infidelity and jealousy and hatred for his lovers, and Angelica was also tormented physically and mentally for her envy and sense of guilt; the Amazons were only to be defeated and killed by the heroes, and Lady Macbeth (Grouch) was also predestined to suffer the failure of usurping the power she and her husband did not deserve. Through the negative examples of Medusa-like Nina, jealous Angelica ("young Juno") and Grouch the "little Amazon" (young Lady Macbeth), Clarke teaches her female readers a good lesson about the destructive power of the animal factor which might be harboured in women in the form of irrational love, jealousy and desire for power, and instructs them banish all these negative feelings, unethical ideas, as well as shrewish and inappropriate behaviours.

In addition to the animal factor that takes the shape of negative feelings and emotions such as twisted love, jealousy and forbidden ambition, characteristics that run counter to the ethics of the Victorian society are regarded as expressive of the animal factor and are only to be uprooted to meet the ethical expectations for women. Katharina is one of the few examples of this in the tales.

Drastically different from her sister Bianca who secured "universal good word" for "her manners, her innocent air, her mild speech, her soft, deprecating, looks" (Clarke 2009: Tale VII, 105), Katharina was despised as "sulky, or indolent, or headstrong, or pert" (Clarke 2009: VII, 109) for her independence, self-assertion, insubordination and straightforward behaviour. In the tale, the rebellious-spirited Katharina was scorned by people of authority, power, or superiority as detesting animals that possessed untamed wild characteristics, i.e., different variations of the animal factor. She was rebuked by her father for shedding "crocodile tears" (Clarke 2009: Tale VII, 113) for the death of her mother; she was compared by Guilio to a "fierce, green-eyed, spread-clawed cat" (Clarke 2009: VII,118) in her childhood; she was a "wicked little lion" and 
JI

a little vixen in the eyes of the lady Abbess (Clarke 2009: Tale VII, 122); she was jokingly called "a sad tigress" and "a wild-cat, - a cat-o'-mountain, - anything fierce, and savage, and fury-like” (Clarke 2009: Tale VII, 166) by Guilio for her unbridled temper when they met again years later. In spite of all this scolding, disciplining, denunciation and even physical punishment, Katharina was determined not to be tamed to be a lamb who ended up becoming a sheep, "a fleecy fool, to be sheared, driven, slaughtered, roasted, and eaten up" (Clarke 2009: Tale VII, 122) and she "cared little for the world's opinion, - slighted it, - set it at defiance” (Clarke 2009: VII, 105). However, under great ethical pressure, she had to change all characteristics that went against the Victorian ethical values and was finally forced to be transformed into a demure lady, in whom the "human factor" (ethical ideas sanctioned by mainstream culture) outweighed the "animal factor" (anything against the accepted ethical rules).

All in all, in Clarke's tales, all characters have to subjugate themselves to double standards of sex and other social ethics, and the dramatically different treatment of the animal factor in the tales testifies again to the ethical double standards for men and women both in and out of tales. While male predators enjoy the game of woman hunting with the unbridled animal factor running wild in their greedy blood, the female victims have to suffer for their ignorance, delinquency and failing to adhere to the ethical rules, with their animal factor or any verisimilitude to that destined to be amputated.

\section{Conclusion}

In such an era when sexual desires were discouraged, topics about sex were almost social taboos, and "repression operated as a sentence to disappear, but also as an injunction to silence, an affirmation of nonexistence, and, by implication, an admission that there was nothing to say about such things, nothing to see, and nothing to know" (Foucault 1978: 4), tales play a significant educating role about sex, sex ethics and social inequalities between men and women. Different from other female writers in that era, Clarke carries out the education in a purposefully horrifying way with examples of lecherous and treacherous male predators as well as repressed and persecuted female victims, and envisages "a simple progression from the 'innocent' interpretations of childhood, through the expanded but still discreetly protected understanding of the adolescent, to the point where the young woman could be trusted to read for herself, and to think 'properly' of any 'gross expressions and unrefined allusions' (Smart ix) contained in the text. What lies beneath this program, however, is the development of a 'shaping discourse' (Stephens 27), pre-empting whatever 
An Ethical Literary Analysis of The Girlhood of Shakespeare's Heroines

personal, possibly unorthodox judgment the reader might be tempted to make with regard to character, action or moral" (Bottoms 2004: 1-2).

Clarke is sympathetic to the unlucky and pathetically weak gender and is devoted to educating Victorian women on such sensitive topics as sex and its double standards as well as other social inequalities and teaching them how to protect themselves under unfavourable conditions. However, while presenting objectively the unfairness and inequalities between men and women in the tales, she strictly observes the Victorian rules and regulations, sticks to the ethical and moral standards of the society, endeavours to meet the social needs to preach and reinforce cultural norms and ethical values, and conforms to the male mainstream literary forms and standards in writing. In the tales, neither does she arrogate to the female characters equal rights and political privileges, nor does she put two genders in extreme opposition or in a superb harmonious relationship. Instead, she depicts straightforwardly the social status quo and its problems, and evokes readers of both genders to be conscious of the very existence of these issues and ethical problems in particular. In other words, it is within the bounds of Victorian ethics and hierarchical and patriarchal social system that Clarke writes tales about Victorian ethics of sex, family, love and marriage, expresses explicitly her concern for female readers and implicitly her attitudes toward such ethics, and ultimately realizes her purpose of promoting Shakespeare and ethical education.

\author{
Ji Rangping \\ jirp215@nenu.edu.cn \\ Foreign Language School of Northeast Normal University \\ 5268 Renmin Street \\ Changchun City \\ Jilin Province 13004 \\ P.R.CHINA
}

\title{
References
}

Bottoms, J. 2004. 'To read aright': Representations of Shakespeare for Children. Children's Literature, 32(1), 1-14.

Clarke, M. C. 2009. The Girlhood of Shakespeare's Heroines in a Series of Fifteen Tales. New York: Cambridge UP.

Foucault, M.1978. The History of Sexuality (Volume 1), transl. from French by R. Hurley. New York: Pantheon Books.

Gross, G. C. 1972. Mary Cowden Clarke, The Girlhood of Shakespeare's Heroines, and the Sex Education of Victorian Women. - Victorian Studies, 16(1), 37-58. 
$\mathrm{JI}$

Nie Zhenzhao. 2011. Ethical Literary Criticism: Ethical Choice and Sphinx Factor. Foreign Literature Studies, 6, 1-13.

Nie Zhenzhao. 2014. Introduction to Ethical Literary Criticism. Beijing: Peking UP.

Osborne, L. E. 2015. Reviving Cowden Clarke: Rewriting Shakespeare's Heroines in Young Adult Fiction. - A. Hansen, K. J. Wetmore Jr., eds., Shakespearean Echoes. New York: Palgrave Macmillan, 21-39.

Pastor, G. et al. 2016. History of Human Sexuality in Western Culture. - http:// historyofsexuality.umwblogs.org/pre-20th-century/victorian-era-2/ (03.05.2018).

Philaretou, A. G. 2008. The Good Life: Moral and Ethical Sexual Considerations. - The Journal of Sex Research, 45(1), 86-87.

Roman, L. \& Roman, M. 2010. Encyclopaedia of Greek and Roman Mythology. New York: Facts on File, Inc.

Victorian Sexuality 2016 = http://www.victoriaspast.com/VictorianSexuality/ VictorianSexuality.html (03.05.2018). 